\title{
Evaluation of Strangpresse Extruder on ORNL BAAM
}
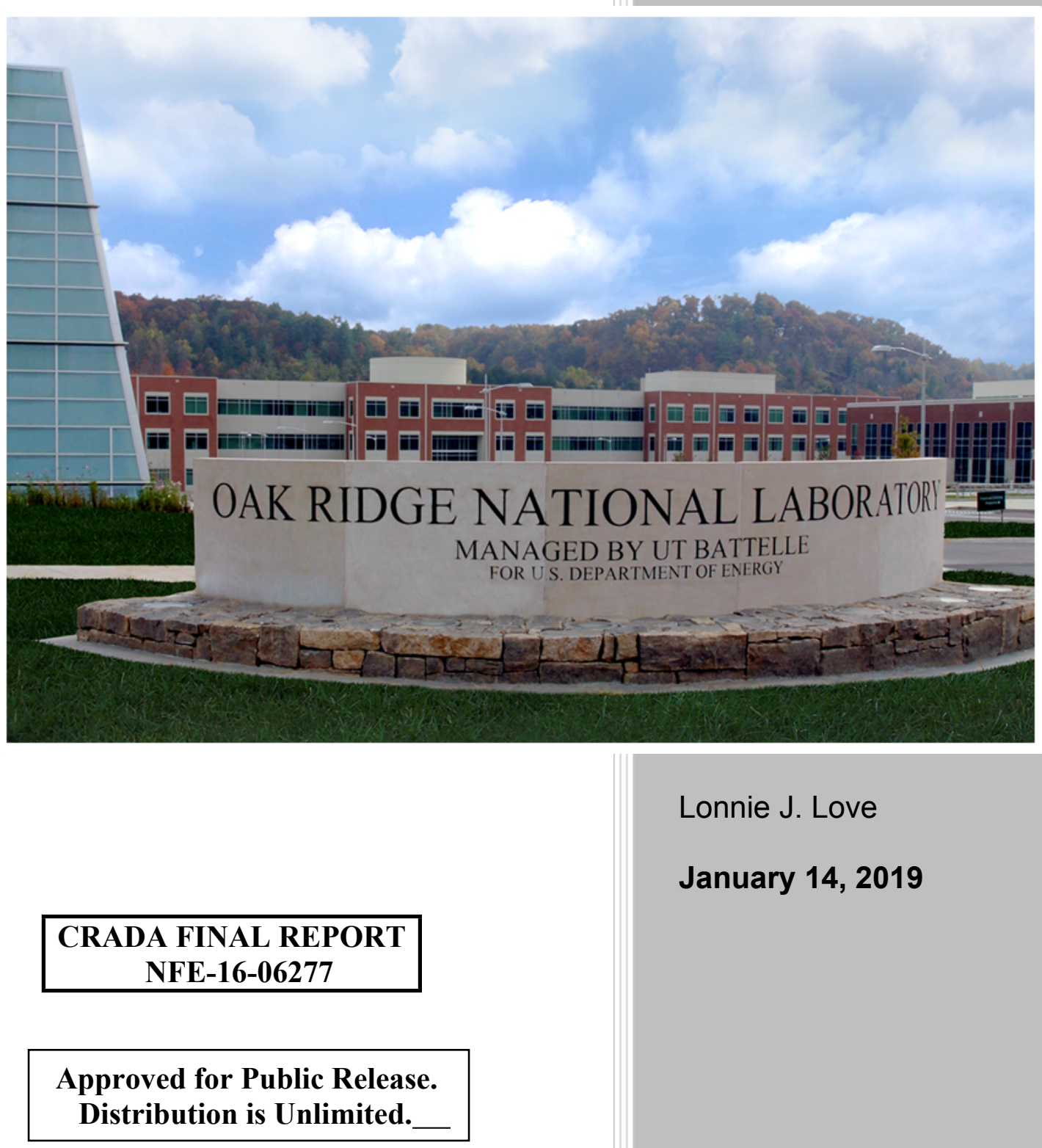

Lonnie J. Love

January 14, 2019 


\section{DOCUMENT AVAILABILITY}

Reports produced after January 1, 1996, are generally available free via US Department of Energy (DOE) SciTech Connect.

Website http://www.osti.gov/scitech/

Reports produced before January 1, 1996, may be purchased by members of the public from the following source:

National Technical Information Service
5285 Port Royal Road
Springfield, VA 22161
Telephone 703-605-6000 (1-800-553-6847)
TDD 703-487-4639
Fax 703-605-6900
E-mail info@ntis.gov
Website http://www.ntis.gov/help/ordermethods.aspx

Reports are available to DOE employees, DOE contractors, Energy Technology Data Exchange representatives, and International Nuclear Information System representatives from the following source:

Office of Scientific and Technical Information

PO Box 62

Oak Ridge, TN 37831

Telephone 865-576-8401

Fax 865-576-5728

E-mail reports@osti.gov

Website http://www.osti.gov/contact.html

This report was prepared as an account of work sponsored by an agency of the United States Government. Neither the United States Government nor any agency thereof, nor any of their employees, makes any warranty, express or implied, or assumes any legal liability or responsibility for the accuracy, completeness, or usefulness of any information, apparatus, product, or process disclosed, or represents that its use would not infringe privately owned rights. Reference herein to any specific commercial product, process, or service by trade name, trademark, manufacturer, or otherwise, does not necessarily constitute or imply its endorsement, recommendation, or favoring by the United States Government or any agency thereof. The views and opinions of authors expressed herein do not necessarily state or reflect those of the United States Government or any agency thereof. 
ORNL/TM-2019/1087

CRADA/NFE-16-06277

Energy and Transportation Sciences Division

Advanced Manufacturing Office

\title{
Evaluation of Strangpresse Extruder on ORNL BAAM
}

\author{
Authors \\ Lonnie J. Love \\ Brian K. Post \\ Phillip C. Chesser \\ Alex Roschli \\ Peter Lloyd \\ Bradley Richardson \\ Alex Boulger
}

Date Published:

January 2019

\author{
Prepared by \\ OAK RIDGE NATIONAL LABORATORY \\ Oak Ridge, Tennessee 37831-6283 \\ managed by \\ UT-BATTELLE, LLC \\ for the \\ US DEPARTMENT OF ENERGY \\ under contract DE-AC05-00OR22725
}

Approved For Public Release 



\section{CONTENTS}

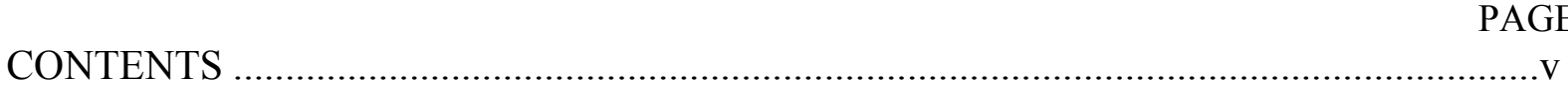

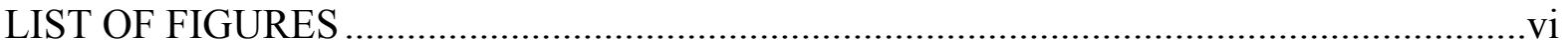

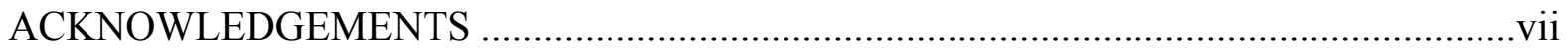

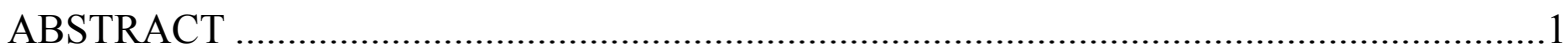

1. EVALUATION OF STRANGPRESSE EXTRUDER ON ORNL BAAM ......................1

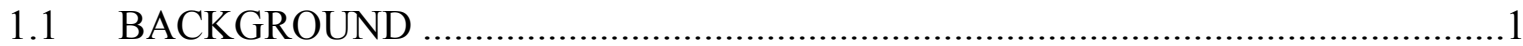

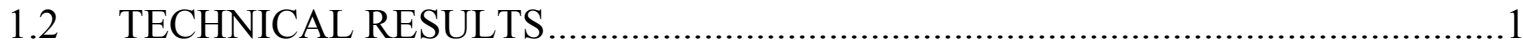

1.2.1 STRANGPRESSE EXTRUDER SYSTEM REQUIREMENTS AND TESTING

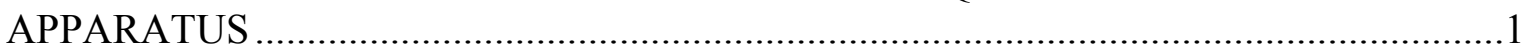

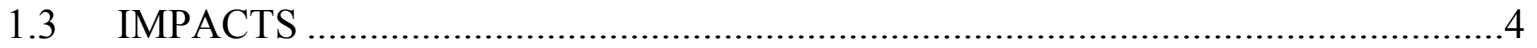

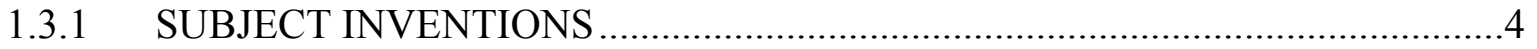

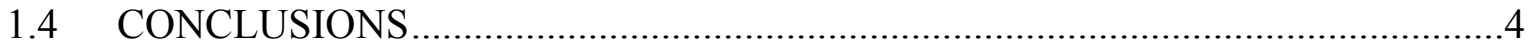

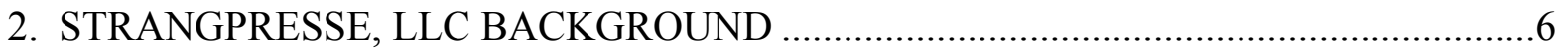




\section{LIST OF FIGURES}

Fig. 1. The small Strangpresse extruder.

Fig. 2. The large Strangpresse extruder.

Fig. 3. The small Strangpresse extruder mounted on its testing apparatus with the extruder control box mounted beside the extruder.

Fig. 4. The large extruder mounted on the back of its testing apparatus (right) and the extruder control box mounted to the front of the testing apparatus (left) 


\section{ACKNOWLEDGEMENTS}

This CRADA NFE-16-06277 was conducted as a Technical Collaboration project within the Oak Ridge National Laboratory (ORNL) Manufacturing Demonstration Facility (MDF) sponsored by the US Department of Energy Advanced Manufacturing Office (CPS Agreement Number 24761).

Opportunities for MDF technical collaborations are listed in the announcement "Manufacturing Demonstration Facility Technology Collaborations for US Manufacturers in Advanced

Manufacturing and Materials Technologies" posted at http:/web.ornl.gov/sci/manufacturing/docs/FBO-ORNL-MDF-2013-2.pdf. The goal of technical collaborations is to engage industry partners to participate in short-term, collaborative projects within the Manufacturing Demonstration Facility (MDF) to assess applicability and of new energy efficient manufacturing technologies. Research sponsored by the U.S. Department of Energy, Office of Energy Efficiency and Renewable Energy, Advanced Manufacturing Office, under contract DE-AC0500OR22725 with UT-Battelle, LLC. 


\begin{abstract}
Researchers at ORNL's Manufacturing Demonstration Facility (MDF) worked with Strangpresse, LLC to demonstrate Strangpresse's newly developed extrusion system. The project tested both a small and large Strangpresse extruder. The project also resulted in Strangpresse exclusively licensing ORNL's some of previously developed extruder technology for high-volume additive manufacturing. The Strangpresse extruder is still under development and testing, however. The next phase of this project could include tasks such as identifying process parameters, making test articles, and quantifying material properties.
\end{abstract}

\title{
1. EVALUATION OF STRANGPRESSE EXTRUDER ON ORNL BAAM
}

This phase I technical collaboration project (MDF-TC-2016-97) began on August 18, 2016 and was completed on January 14, 2019. The collaboration partner, Strangpresse, LLC, is a small business. Phase I resulted in successful system requirements identification and bench test system integration. Strangpresse has also exclusively licensed previously developed additive manufacturing-related extruder technology from the Department of Energy's Oak Ridge National Laboratory. This technology will result in larger printed parts and quicker rates and improved quality of polymer deposition.

\subsection{BACKGROUND}

Strangpresse, LLC has developed a new polymer extrusion system capable of extruding more than $100 \mathrm{lbs}$. of material per hour. The company's goal is to develop a product line of extruders that have high performance (high flow and high response time) that can be marketed to Big Area Additive Manufacturing (BAAM) manufacturers such as Thermwood, Ingersoll, and Cincinnati Incorporated, among others. By partnering with the MDF, Strangpresse obtained unbiased analysis on their products' performance by experts in additive manufacturing. ORNL can likewise help Strangpresse evaluate product refinements that can improve product quality and U.S. competitiveness.

\subsection{TECHNICAL RESULTS}

\subsubsection{STRANGPRESSE EXTRUDER SYSTEM REQUIREMENTS AND TESTING APPARATUS}

This project resulted in determining system requirements necessary for both a small (Figure 1) and large (Figure 2) Strangpresse extruder for a fully functional extruding system. The small extruder is a Model 10, while the large extruder is a Model 30. Neither extruder requires compressed air to operate unless the extruder is using a vacuum feed line to send material to the extruder. The power requirements to operate the small extruder are $240 \mathrm{~V}$ and $30 \mathrm{~A}$. The power requirements to operate the large extruder are 480V, 3-Phase, and 50A. 


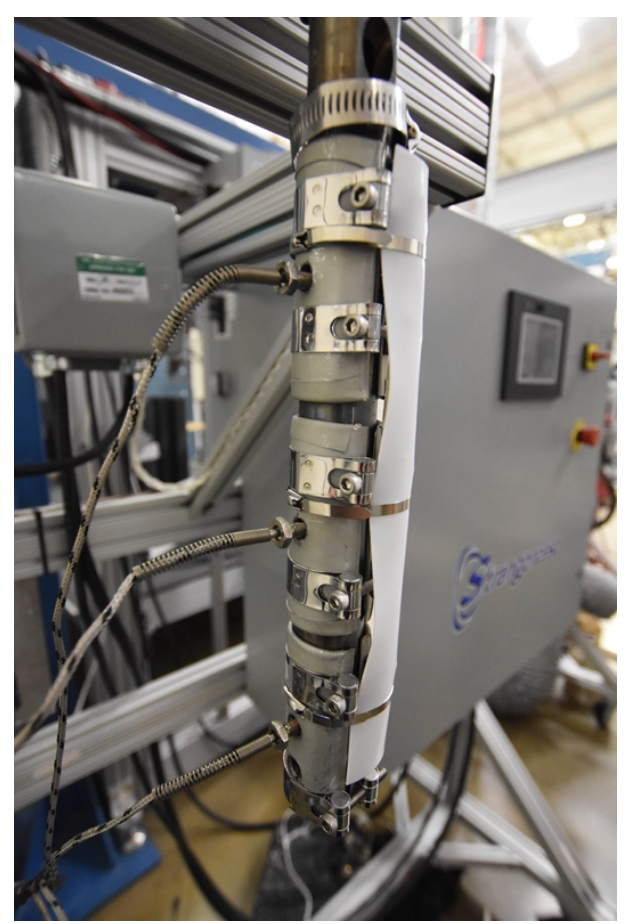

Fig. 1. The small Strangpresse extruder.

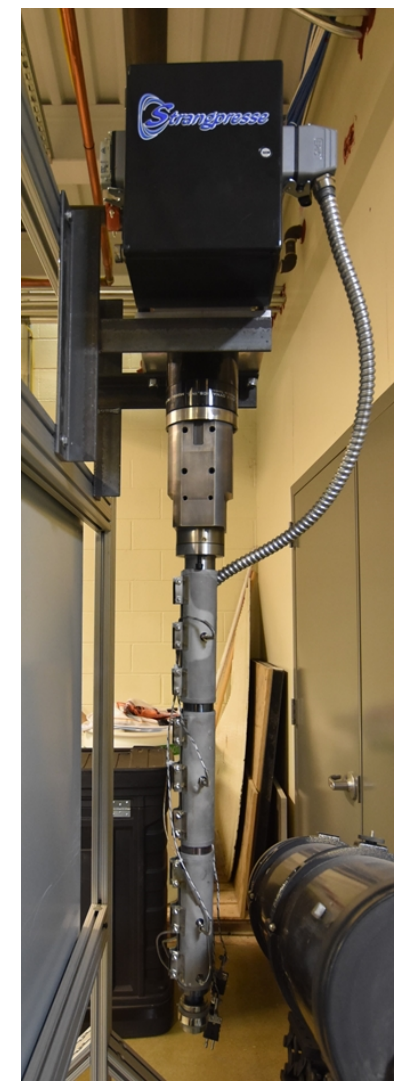

Fig. 2. The large Strangpresse extruder. 
The MDF manufactured a bench top apparatus for both the small and large extruders. Each testing apparatus included physical, electrical, and computation connections and can be seen in Figures 3 and 4.

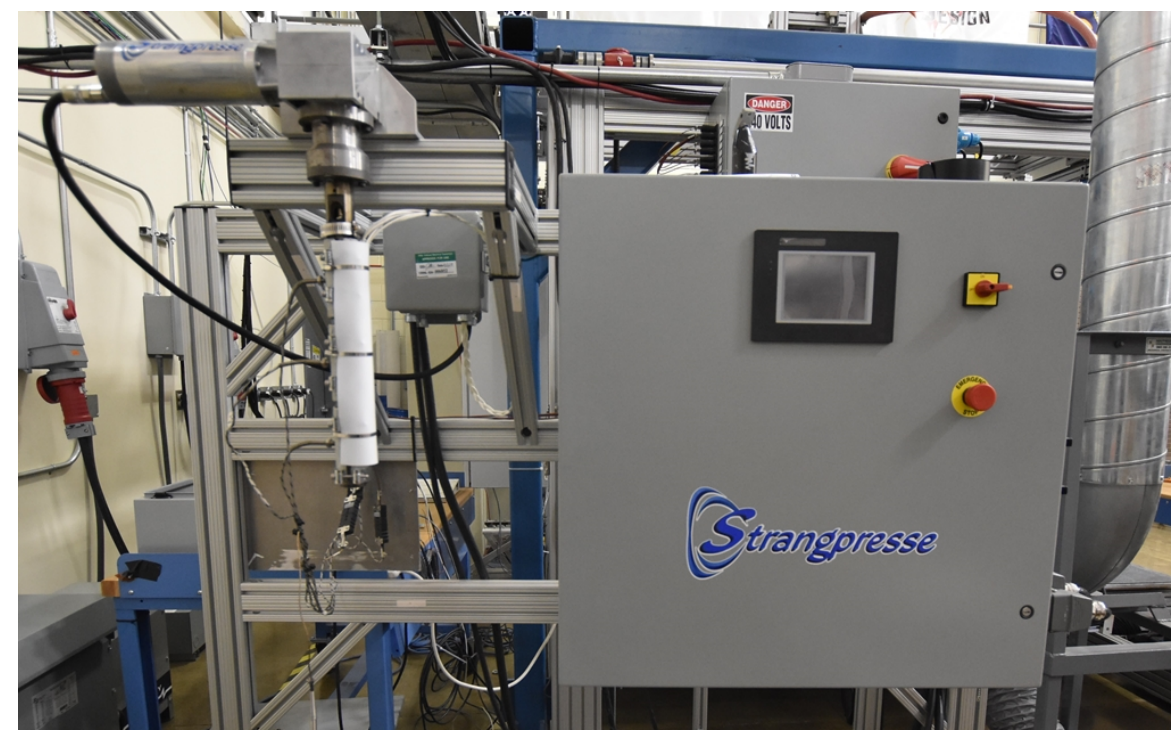

Fig. 3. The small Strangpresse extruder mounted on its testing apparatus with the extruder control box mounted beside the extruder.
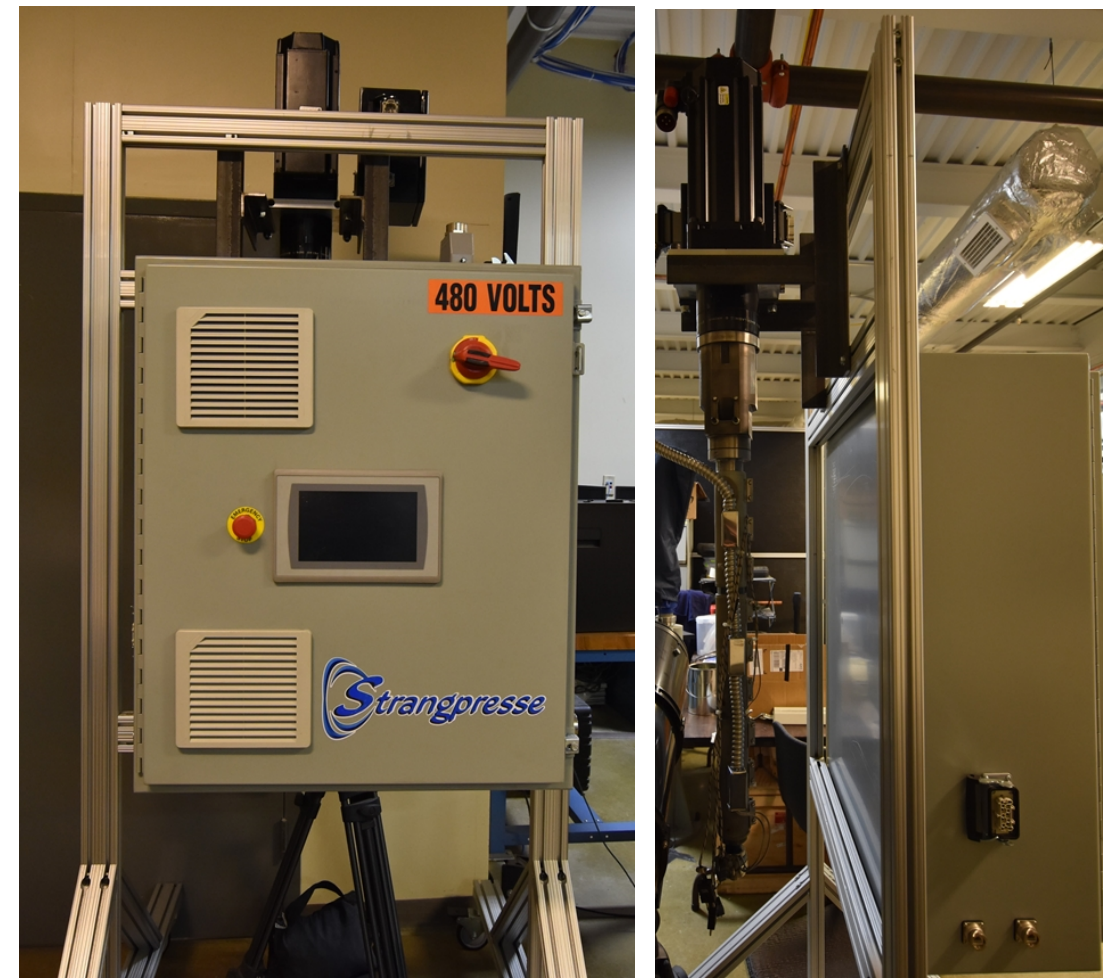

Fig. 4. The large extruder mounted on the back of its testing apparatus (right) and the extruder control box mounted to the front of the testing apparatus (left). 
Both Strangpresse extruders are still under development, but the exclusive licensing agreement of previously developed technology between Strangpresse and ORNL that was a direct result of this project will enable Strangpresse to move forward with their objective to to develop a series of extruders that can be rapidly manufactured and marketed to BAAM system integrators.

\subsection{IMPACTS}

While there is great potential for BAAM, the commercialization of a high-performance extruder for BAAM is critical for commercial success of this emerging technology. This process is on its way to reality with Strangpresse's exclusive licensing of ORNL's extruder technology for high-volume additive manufacturing. Strangpresse licensed an ORNL invention for an extruder nozzle that enables faster material deposition and finer print resolution and another invention that drastically improves printer starts and stops on extrusion prints for large area printed objects, leading to improved part quality with minimal roughness at print seams.

This success will increase the ease and frequency at which BAAM is introduced to new companies that will invest in the technology, which has the potential to revolutionize the U.S. manufacturing industry. Additionally, Strangpresse has a company goal to be the leading innovator of high-performance extruders for BAAM, and this project will be instrumental in that success.

\subsubsection{SUBJECT INVENTIONS}

There are no new subject inventions as a result of this project.

\subsection{CONCLUSIONS}

This first phase of this technical collaboration resulted in the coordination of system requirements and the creation of a bench test apparatus for the Strangpresse extruders.

Follow-on efforts may include further development and testing of a Strangpresse extruder through the integration of a Strangpresse extruder onto a large-scale additive manufacturing system. This will require mechanical, electrical, and computational modifications to the system. Additionally, materials testing will be done with a final goal of fully evaluating an optimal material using the Strangpresse extruder, and processing parameters will be developed according to the evaluated material and extruder. Then, test articles will be manufactured to measure material properties of strength and stiffness. Lastly, together ORNL and Strangpresse will identify and manufacture a test article that demonstrates the performance of the extruder. Candidate articles include composite tooling or end use replacement parts for legacy equipment.

This technology collaboration is a key example of what can result when researchers collaborate with industry leaders. 


\section{STRANGPRESSE, LLC BACKGROUND}

Strangpresse was founded in 2014 in Youngstown, Ohio, to research, develop, and commercialize fully controllable, lightweight, thermoplastic extruders to be used primarily in additive manufacturing. Strangpresse was the first company to license Oak Ridge National Laboratory's suite of patents associated with large-scale additive manufacturing.

The Strangpresse leadership team has more than 70 years of experience in the thermoplastic extrusion industry. In addition to our licensing agreement with ORNL, Strangpresse have partnered with Rockwell Automation's original equipment manufacturer team to continue its development of control and monitoring systems for its extrusion equipment.

Strangpresse's founders hold many patents related to the processing of thermoplastics, some of which the company has licensed for use in the additive manufacturing industry. Through this technology, Strangpresse has overcome many issues related to consistent throughput and melt quality of output volumes, stopping and starting, and nozzle orifice diameter. Strangpresse's products are used in the rapid prototyping and manufacture of finished structures, tooling, molds, and dies. 